\title{
EFEKTIVITAS INTERVENSI COGNITIVE BEHAVIOR THERAPY (CBT) UNTUK MENURUNKAN PERILAKU MARAH PADA ANAK SEKOLAH DASAR
}

\section{EFFECTIVENESS OF INTERVENTION OF COGNITIVE BEHAVIOR THERAPY (CBT) TO REDUCE ANGRY BEHAVIOR IN ELEMENTARY SCHOOL CHILDREN}

\author{
Kurniawati Budi Rahayu ${ }^{1}$, Rahma Widyana ${ }^{2}$ \\ ${ }^{1}$ SDN 2 Sedeng, Dinas Pendidikan Kabupaten Pacitan, ${ }^{2}$ Universitas Mercu Buana Yogyakarta \\ ${ }^{1}$ rhytmfree@gmail.com
}

\begin{abstract}
Abstrak
Penelitian ini bertujuan untuk mengetahui efektivitas intervensi Cognitive Behavior Therapy (CBT) untuk menurunkan perilaku marah pada anak Sekolah Dasar. Hipotesis y ang diajukan pada panelitian ini adalah ada perbedaan frekuensi perilaku marah pada anak usia Sekolah Dasar sebelum dan sesudah mendapatkan perlakuan menggunakan Cognitive Behavior Therapy(CBT), Perilaku marah setelah perlakuan menggunakan CBT menurun. Subjek dalam penelitian ini berjumlah 2 orang siswa. Desain yang digunakan dalam penelitian ini adalah single case study berupa pengaruh intervensi Cognitive Behavior Therapy $(C B T)$. Metode analisis yang digunakan adalah analisis visual inspection; analisis kualitatif yang diperoleh dari wawancara, observasi, dan catatan marah subjek; serta analisis kuantitatif menggunakan analisis non parametric (Wilcoxon). Hasil uji hipotesis pada penelitian ini pada subjek $D$ sebesar $Z=-2,207$ dengan nilai $p=0,027<0,050$, dan pada subjek A diperoleh besaran $\mathrm{Z}=-2,201$ dengan nilai $\mathrm{p}=0,028<0,050$. Berdasarkan anaalisis tersebut diperoleh kesimpulan bahwa ada perbedaan signifikan frekuensi perilaku marah pada subjek sebelum dan sesudah memperoleh intervensi Cognitive Behavior Therapy (CBT). Intervensi Cognitive Behavior Therapy $(C B T)$ efektif untuk menurunkan frekuensi perilaku marah pada anak usia Sekolah Dasar.
\end{abstract}

Kata kunci: cognitive behavior therapy (CBT), perilaku marah anak usia sekolah dasar

\begin{abstract}
This study aimed to determine the effectiveness of Cognitive Behavior Therapy (CBT) interventions to reduce angry behavior in elementary school children. The hypothesis proposed in this study is that there are differences in the frequency of angry behavior in elementary school-age children before and after getting treatment using Cognitive Behavior Therapy (CBT). Angry behavior after treatment using CBT decreases. The subjects in this study were two students. The design used in this study is a single case study in the form of the influence of the Cognitive Behavior Therapy (CBT) intervention. The analytical method used is visual inspection analysis; qualitative analysis obtained from interviews, observations, and angry notes of the subjects; and quantitative analysis using non-parametric analys is (Wilcoxon). The results of hypothesis testing in this study in subject $D$ were $Z=-2.207$ with a value of $p=0.027<0.050$, and in subject $A$ obtained the amount of $Z=-2.201$ with a value of $p=0.028<0.050$. Based on the analysis, it is concluded that there were significant differences in the frequency of angry behavior in the subject before and after obtaining the Cognitive Behavior Therapy $(C B T)$ intervention. The intervention of Cognitive Be havior The rapy $(C B T)$ is effective in reducing the frequency of angry behavior in elementary school-age children.
\end{abstract}

Keywords: cognitive behavior therapy $(C B T)$, angry behavior in elementary school-age children

\section{PENDAHULUAN}

Emosi adalah salah satu aspek penting perkembangan yang terdapat pada setiap manusia. Emosi adalah perasaan atau afeksi yang timbul ketika seseorang sedang berada dalam suatu keadaan atau suatu interaksi yang dianggap penting, terutama berhungan dengan keberadaan dirinya (Compos dalam Santrock, 2007). Goleman (1995), menyatakan bahwa emosi merujuk pada suatu perasaan atau pikiran-pikiran khasnya, suatu keadaan biologis dan psikologis serta 
serangkaian kecenderungan untuk bertindak. Emosi diwakili oleh perilaku yang mengekspresikan kenyamanan atau ketidaknyamanan terhadap keadaan atau interaksi yang sedang dialami. Secara umum terdapat dua macam emosi pada manusia yaitu emosi positif dan emosi negatif. Contoh emosi positif adalah antusiasme, bahagia, rasa senang, dan cinta, sedangkan contoh emosi negatif adalah cemas, marah, rasa bersalah, dan rasa sedih. Walaupun marah termasuk sebagai emosi negatif, akan tetapi kemunculan marah tidak selalu menjadi tanda dari adanya ketidakstabilan emosi, melainkan merupakan emosi alami yang dialami oleh setiap orang baik itu anak-anak, remaja, dan orang dewasa (Golden, 2003).

Menurut Faupel, Herrick dan Sharp (2011), ketika berhadapan dengan rasa marah, maka tiap individu akan mengekspresikannya dengan berbagai cara. Marah merupakan reaksi emosi yang wajar apabila mampu diekspresikan dengan perilaku yang efektif atau disebut juga dengan normal anger. Ketika marah diekspresikan secara efektif, hal ini memberikan kesempatan bagi individu untuk belajar dan bagaimana menyelesaikan masalah dengan cara yang adaptif. Pada anak-anak, bentuk pengekspresian rasa marah biasanya ditunjukkan dengan perilaku yang agresif, misalnya pada saat anak marah diekspresikan dengan tantrum, mengamuk, merusak barang, membanting pintu, dan perilaku merusak lainnya, yang dapat mengganggu hubungan anak dengan orangtua, dengan anggota keluarga yang lain, dengan teman di lingkungan, dengan guru dan teman di sekolah, dan dengan lingkungan sekitar di mana anak tersebut tingga (Faupel, Herrick \& Sharp, 2011). Golden (2003) berpendapat bahwa kemampuan anak dalam berperilaku marah terg antung sejauh mana anak dapat merasa nyaman dalam mengekspresikan emosi dan pikiran terhadap orang lain sebagai sumber konflik.

Terdapat berbagai macam hal yang dapat menyebabkan munculnya perilaku marah anak. Hal yang paling sering dapat menyebabkan munculnya perilaku marah adalah ketika anak menghadapi suatu situasi yang tidak sesuai dengan apa yang diharapkannya. Perilaku marah juga dapat muncul sebagai reaksi dari perasaan frustrasi ataupun kecewa ketika memiliki keinginan yang tidak terpenuhi (Bhave \& Saini, 2009). Hal ini didukung oleh penelitian yang dilakukan oleh Faupel, Herrick dan Sharp (2011) di mana anak terkadang memiliki kesulitan dalam menampilkan perilaku yang dapat diterima oleh lingkungan ketika keinginan anak tidak terpenuhi.

Seperti yang terjadi pada subjek (D) yang berusia 9 tahun, dan subjek (A) yang berusia 11 tahun. Berdasarkan hasil wawancara dan observasi yang dilakukan peneliti, pada subjek (D) diperoleh data yaitu subjek duduk di kelas $3 \mathrm{SD}$, mulai hari pertama subjek masuk sekolah, subjek sering menunjukkan perilaku marah, disertai dengan merusak dan melempar barang, serta berkelahi dengan teman. Subjek baru saja pindah dari Jakarta ke Pacitan untuk tinggal bersama dengan orangtua, sebelumnya subjek di Jakarta tinggal dengan kakek dan neneknya. Menurut pendapat guru, subjek adalah anak yang nakal dan susah diatur, subjek tidak disukai teman-temannya, bahkan guru kelasnya takut untuk mendekati dan menenangkan subjek saat marah. Terdapat hal-hal sepele yang cepat membuat subjek marah, seperti tidak dituruti ketika menginginkan sesu atu, at au 
tidak dipinjami teman penghapus. Menurut Brooks (2011), marah yang dimunculkan oleh subjek (D) karena anak meyakini bahwa anak harus mendapatkan yang diinginkan, sehingga anak akan berusaha sekuat mungkin hingga menjadi marah untuk mendapatkan keinginannya.

Sedang pada subjek (A) diperoleh data, subjek berusia 11 tahun dan duduk di kelas 5 SD, berasal dari keluarga dengan ekonomi di bawah rata-rata dan hanya diasuh oleh ibunya, karena ayahnya sudah meninggal saat subjek duduk di kelas 3 SD. Perilaku marah yang ditunjukkan subjek yaitu memaki, berkata kasar, membentak dengan suara keras, menantang berkelahi, dan membanting benda di sekitarnya. Menurut pendapat guru, subjek berperilaku marah untuk menarik perhatian guru, hal ini dikarenakan kurang kasih sayang dari sosok ayah. Subjek juga mudah tersinggung dan salah paham serta menganggap guru dan teman meremehkannya karena subjek adalah anak dari keluarga miskin. Hal-hal yang tidak ada sangkut pautnya dengan status ekonomi subjek selalu dikait-kaitkan subjek dengan status ekonomi keluarganya. Perilaku marah yang ditampilkan subjek (A) disebabkan rendahnya pemahaman kognitif sosialnya, sehingga mudah terpancing emosinya, mudah tersinggung, marah, dan kurang dalam pemecahan masalahnya. Menurut Geldrad dan Geldrad (2012), cara anak memandang atau melihat dirinya sangat kuat hubungannya dengan gagasan dan kepercayaan yang dimiliki tentang dirinya.

Sebenarnya ketika subjek (D) tidak dalam kondisi marah, subjek dapat belajar dan bergaul seperti anak lain di kelasnya. Ketika mood-nya bagus, subjek dapat bermain dan belajar dengan tenang serta mudah diatur, bahkan subjek termasuk anak yang pandai di kelasnya. Akan tetapi, subjek mudah sekali marah bahkan oleh hal-hal kecil yang terjadi, seperti misal saat temannya tidak mau meminjamkan penghapusnya, subjek kemudian melempar penghapus temannya lewat jendela kelas, dan mengakibatkan temannya menangis. Begitu pula dengan subjek (A), apabila tidak dalam kondisi marah, subjek adalah anak yang periang, akrab dengan teman di kelasnya, bahkan menjadi idola untuk adik-adik kelasnya, subjek juga mudah diajak untuk bekerja sama. Akan tetapi subjek sering marah tanpa alasan jelas, misal saat ibu guru menanyakan mengapa subjek ke sekolah tidak memakai sepatu, dan menyuruh subjek pulang untuk mengganti sandal yang dipakai dengan sepatu, subjek langsung marah dan mengatakan bahwa subjek adalah anak dari keluarga miskin sehingga tidak boleh bersekolah dan mengenyam pendidikan seperti temanteman yang lain.

Bhave dan Saini (2009) berpendapat bahwa emosi marah yang diekspresikan dengan perilaku yang tidak efektif muncul sebagai akibat dari adanya persepsi yang salah mengenai lingkungan. Faupel, Herrick dan Sharp (2011) mengungkapkan, persepsi tersebut tidak hanya mempengaruhi bagaimana marah muncul, namun juga mempengaruhi bagaimana individu tersebut menjadi irasional dan mengekspresikan marah dengan cara dan perilaku yang tidak efektif. Hal tersebut membuat individu menjadi tidak dapat melihat suatu permasalahan dari sudut pandang orang lain dan kurang dapat bersikap empati terhadap orang lain. Kemampuan berpikir secara rasional hilang ketika individu tidak dapat mengendalikan rasa marah. 
Cara-cara yang biasa digunakan dalam mengekspresikan rasa marah (Goleman, 1997) adalah sebagai berikut, antara lain repression, yaitu mengalami perasaan marah tetapi segera melupakan perasaan marahnya. Displacement, yaitu memiliki perasaan marah terhadap seseorang atau benda yang sebenarnya bukan orang atau benda tersebut target dari amarahnya. Controlling, yaitu menahan dan mengendalikan secara emosional badai amarah yang sedang berlangsung dalam dirinya. Suppression, yaitu mengalami perasaan marah tetapi dipendam, sehingga tidak ada pengekspresian marah tersebut. Quiet crying, penekanan perasaan marah dengan tanpa proses verbal atau fisik. Cara ini dapat meredakan emosi amarah dan mengubahnya menjadi kesedihan dan perasaan sakit dalam diri orang tersebut. Assertive confrontation, yaitu suatu respon langsung yang tegas terhadap seseorang atau benda yang membuat atau membangkit amarah. Overreaction, merusak atau menyakiti secara fisik suatu benda atau seseorang yang sebenarnya benda at au orang tersebut bukan sasaran amarah yang sesungguhnya.

Dari pengertian di atas, dapat disimpulkan bahwa perilaku marah adalah suatu kondisi emosional negatif yang dapat mempengaruhi perubahan kognisi dan psikologis pada seseorang. Ketika seseorang merasakan marah, maka akan terjadi perubahan -perubahan fisik yang mendukung seperti ekspresi wajah, ketegangan otot, dan juga terkadang perubahan pada sistem syaraf, yang termanifestasi pada kegiatan atau perilaku, baik yang dapat diamati langsung, maupun yang tidak dapat diamati oleh pihak luar, yang merupakan hasil dari pengalaman subjektif seseorang terhadap orang lain atau terhadap suatu situasi yang dipersepsikan sebagai keadaan yang tidak menyenangkan.

Faktor-faktor yang mempengaruhi perilaku marah menurut Mash dan Wolfe (2005) adalah sebagai berikut, yang pertama adalah faktor individu dimana disebabkan oleh temperamental dan distorsi kognitif. Yang kedua adalah faktor keluarga, yaitu diantaranya adalah pola asuh yang diterapkan oleh orangtua serta hubungan antara orangtua dan anak. Dan yang ketiga adalah faktor lingkungan, dalam hal ini adalah peran belajar. Menurut Hidayati dan Wahyu (2015), ketika individu belajar mengendalikan perilaku marahnya, secara bertahap individu tersebut bisa lebih mudah mengalihkan marah pada hal-hal yang berisfat positif. Sebaliknya, bila dibiarkan dengan perilaku marahnya, individu tersebut akan belajar terus menerus untuk menggunakan kemarahan demi memperoleh keinginannya.

Pada usia 7-12 tahun, anak mulai dapat mengatur ekspresi emosi dalam situasi sosial dan dapat berespon terhadap distress emosional yang terjadi pada orang lain, dan mulai dapat mengontrol emosi negatif seperti takut dan sedih. Anak belajar apa yang membuat dirinya sedih, marah, atau takut sehingga belajar beradaptasi agar emosi tersebut dapat dikontrol (Suriadi \& Yuliani, 2006). Anak memahami bahwa mengekspresikan emosi negatif seperti marah melalui perilaku agresif merupakan hal yang tidak dapat diterima oleh lingkungan, namun terkadang memiliki kesulitan dalam meregulasi emosi marah dibandingkan emosi sedih (Lemerise \& Harper, 2010). Keberhasilan anak dalam mengelola rasa marah sehingga tidak termanifestasi dalam 
perilaku agresif membutuhkan kemampuan untuk mengenali dan memahami emosi yang dimiliki, sehingga anak dapat menampilkan perilaku yang dapat diterima oleh lingkungan dan membantu dalam menghadapi berbagai masalah (Lemerise \& Harper, 2010). Namun hal yang terjadi pada subjek yaitu belum dapat sepenuhnya mengontrol emosi marahnya, sehingga termanifestasi dalam perilaku marah yang agresif hanya dikarenakan hal yang sepele. Perilaku marah subjek yang agresif membuat subjek ditakuti oleh orangtua, keluarga, guru, dan teman di sekolahnya.

Ketika anak mampu menampilkan berbagai emosi yang dimiliki dalam perilaku yang dapat diterima lingkungan, anak mengembangkan citra diri yang positif serta sikap yang optimis, yang akan membantu menghadapi berbagai tantangan yang berhubungan dengan emosi di masa depan. Anak yang memiliki kesulitan dalam mengekspresikan emosi, secara umum memiliki mood, rasa empati dan kemampuan sosial yang juga tidak terlalu baik. Anak terlalu banyak merasakan emosi negatif, sehingga mengganggu kemampuan anak dalam berempati dan bersosialisasi (Berk, 2008).

Eisenberg dan Morris (dalam Kail, 2010) mengemukakan bahwa tidak semua anak dapat mengungkapkan emosi marah dengan baik. Akibat yang dapat muncul dari kesulitan mengungkapkan marah secara tepat pada anak-anak menurut Faupel, Herrick dan Sharp (2011), dapat mengganggu hubungan anak dengan teman sebayanya ataupun anggota keluarga. Di dalam keluarga, orangtua akan merasa frustasi ketika tidak lagi mampu menghadapi kemarahan dari anak. Hal ini tentunya akan mengganggu hubungan antara orangtua dan anak. Dalam lingkungan pertemanan, anak mempunyai perilaku marah yang berlebihan tidak disenangi oleh temantemannya karena dianggap mengganggu dan tidak dapat dipercaya.

Selain itu, Fabes (dalam Kail, 2010) mengatakan bahwa ketika anak sulit mengekspresikan marah dalam perilaku yang dapat diterima lingkungan, maka akan mengalami kesulitan dalam mencari jalan keluar yang baik saat berhadapan dengan masalah di kehidupannya. Misalnya, ketika seorang anak berdebat mengenai permainan yang ingin dimainkannya, anak akan sulit untuk mencari solusi dan bernegoisasi dengan baik dalam memperoleh keinginannya karena lebih mengutamakan mengekspresikan marahnya ke dalam perilaku yang agresif.

Anak usia 7-12 tahun mulai memahami bahwa mengekspresikan emosi negatif seperti marah melalui perilaku agresif merupakan hal yang tidak dapat diterima oleh lingkungan, namun terkadang anak memiliki kesulitan dalam pengendalian emosi marah dibandingkan emosi sedih (Lemerise \& Harper, 2010).

Berdasarkan pengertian diatas, maka dapat disimpulkan bahwa anak usia 7-12 tahun mulai memahami bahwa mengekspresikan emosi negatif seperti marah melalui perilaku agresif merupakan hal yang tidak dapat diterima oleh lingkungan. Keberhasilan anak dalam mengelola rasa marah membutuhkan kemampuan untuk mengenali dan memahami emosi yang dimiliki, sehingga dapat menampilkan perilaku marah yang dapat diterima oleh lingkungan dan membantu anak dalam menghadapi berbagai masalah. 
Menurut Bhave dan Saini (2009), individu yang memiliki perilaku marah, memiliki pemikiran yang negatif mengenai lingkungannya. Anak-anak tidak menyadari bahwa reaksi marah yang ditampilkan disebabkan oleh kesalahan berpikir (irrational belief) yang dimiliki. Kesulitan pada anak yang mempunyai perilaku marah yang agresif juga dapat menyebabkan munculnya gangguan-gangguan psikopatologis di samping gangguan fisik. Beberapa akibat yang dapat muncul dari kesulitan dalam mengelola rasa marah dan mengekspresikannya dalam perilaku marah di antaranya adalah depresi, perasaan bersalah, malu, tidak dapat mengendalikan diri, serta kehilangan rasa percaya diri ketika berhadapan dengan orang lain. Secara spesifik, dampak dari perilaku marah pada anak adalah adanya kesulitan atau kegagalan dalam menjalin hubungan dengan orang lain serta tidak menutup kemungkinan munculnya tingkah laku kekerasan terhadap diri sendiri mau pu n orang lain (Faupel, Herrick \& Sharp, 2011).

Untuk menghindari terjadinya dampak negatif dari pengekspresian rasa marah yang berlebihan, maka perlu dilakukan intervensi tertentu. Pada penelitian ini, peneliti akan menggunakan intervensi Cognitive Behavior Therapy (CBT) untuk mengatasi perilaku marah pada anak. Hal ini didukung oleh pernyataan yang dikemukakan oleh Adelman dan Taylor (dalam Kurniawan, 2014) yang menyatakan bahwa CBT sangat dimungkinkan diberikan kepada anak hingga remaja dengan gangguan perilaku, seperti perilaku marah, perilaku menentang, dan perilaku merusak. CBT tidak hanya berfokus terhadap perubahan syaraf yang ada pada tubuh atau pun pada perubahan tingkah laku, akan tetapi lebih kepada adanya distorsi kognitif pada subjek dan dengan mengikuti terapi diharapkan dapat membantu penyelesaian masalah psikologis subjek (Vicker, 2002). Asumsi dasar dari pendekatan CBT adalah tingkah laku yang overt dipengaruhi oleh proses kognitif, dan proses ini dapat mempengaruhi tingkah laku seseorang. Terapi CBT yang diberikan berhubungan dengan kemampuan sosial, problem solving, dan anger management (Kazdin et al., 1997).

Kemunculan masalah yang menjadi faktor penyebab terjadinya perilaku marah berhubungan dengan adanya keyakinan dan distorsi kognitif yang salah dalam menghadapi suatu permasalah an. Silverman dan DiGiuseppe (2001) mengatakan bahwa masalah emosi dan tingkah laku yang ada pada anak muncul sebagai hasil dari adanya disfungsi kognitif ataupun pikiran yang irrasional. Pada subjek (D), disfungsi kognitif yang terjadi adalah subjek mempunyai persepsi bahwa segala keinginan subjek harus dipenuhi, sedang pada subjek (A) mempunyai persepsi orang lain akan menghina subjek karena keadaan ekonominya yang kurang mampu. Stallard (2002) mengemukakan bahwa terdapat hubungan yang kuat antara distorsi kognitif dengan munculnya gangguan psikopatologis pada anak. Temuan ini menguatkan hasil penelitian meta analisis yang dilakukan oleh Feindler dan Engel (2011), bahwa bagian tersulit dalam memberikan intervensi kepada subjek yang berperilaku agresif saat marah adalah melatih untuk melakukan restukturulang atau mengubah dialog internal yang dimiliki. Melalui intervensi dengan CBT, intervensi tidak 
hanya berfokus pada perubahan tingkah laku tetapi juga terhadap kognitif yang mempengaruhi tingkah laku anak, agar perilaku marah yang dimunculkan dapat lebih diterima oleh lingkungan.

Menurut Beck, Richard \& Fernandez, Ephrem.(1998), salah satu intervensi yang dapat diberikan pada anak dengan masalah rasa marah adalah Cognitive Behavior Therapy (CBT). CBT tidak hanya berfokus terhadap perubahan syaraf yang ada pada tubuh ataupun pada perubahan tingkah laku, akan tetapi lebih kepada adanya distorsi kognitif pada subjek, dan dengan mengikuti terapi diharapkan dapat membantu penyelesaian masalah psikologis subjek. Minde (2010) intervensi dengan CBT sesuai untuk membantu anak dengan masalah emosi marah, serta dapat diterapkan kepada anak usia sekolah dasar. Atas dasar tersebut, CBT dipandang sebagai intervensi yang lebih sesuai untuk diterapkan terhadap subjek. Diharapkan dengan CBT, maka distorsi kognitif subjek dapat berubah, sehingga intensitas perilaku marah subjek menurun, dan perilaku marah yang ditampilkan subjek lebih adaptif dan dapat diterima oleh lingkungan. Dalam penelitian ini peneliti ingin melihat sejauh mana efektivitas dari CBT yang diberikan dapat memberikan perubahan terhadap aspek kognitif, emosi, dan perilaku ketika subjek dihadapkan pada situasi yang membuat marah.

Berdasarkan tinjauan teoritis dan penggalian data permasalahan yang dilakukan penulis, pertanyaan dalam penelitian ini adalah: "Apakah intervensi dengan Cognitive Behavior Therapy (CBT) dapat menurunkan frekuensi perilaku marah pada anak usia Sekolah Dasar?"

\section{METODE}

Variabel dalam penelitian ini adalah penurunan perilaku marah dengan interven si Cognitive Behavior Therapy (CBT). Definisi penurunan perilaku marah dengan intervensi Cognitive Behavior Therapy $(C B T)$ secara operasional adalah penurunan perilaku marah yang biasanya ditampilkan dengan perilaku yang meledak-ledak seperti berteriak, berkelahi, memukul, menggigit, dan mengamuk dengan intervensi Cognitive Behavior Therapy (CBT) yaitu intervensi yang memperhatikan mengenai proses kognitif yang terjadi pada subjek dan bagaimana hubungannya dengan perubahan emosi dan tingkah laku subjek. Subjek anak usia Sekolah Dasar, maka perlu dilakukan penyesuaian, misalnya menggunakan lebih banyak teknik non-verbal dibandingkan dengan teknik verbal dengan mempertimbangkan kemampuan kognitif anak dengan penggunaan boneka tangan, storytelling, visualisasi atau imagery gambar kartun, thought bubbles, dan berbagai cara non-verbal (Stallard, 2005).

Perilaku marah akan diukur dengan observasi behavior checklist yang peneliti buat berdasarkan beberapa perilaku yang mengindikasikan masalah dalam pengelolaan rasa marah anak menurut Borba (2009), yang meliputi: sering marah meledak-ledak; tidak mampu menjelaskan perasaan saat marah; kesulitan menenangkan diri saat merasa frustasi atau kesal; menyerang secara fisik; menyerang secara verbal; menyalahkan oranglain terhadap perilaku marahnya; tidak perduli terhadap perasaan orang lain; butuh diingatkan, dibujuk, ditegur, untuk mengendalikan emosi 
marah; tantrum; memendam perasaan; dan bicara, menulis atau menggambar tentang kekerasan. Behavior checklist ini dilengkapi dengan wawancara dan catatan perilaku marah subjek, yang diberikan kepada orangtua, pengasuh, dan guru sebagai tambahan informasi. Materi CBT yang akan digunakan untuk menurunkan perilaku marah subjek menerapkan teknik CBT yang mendasarkan prinsip CBT dari Novaco (Taylor \& Novaco, 2005) dan Stallard (2005) yaitu berupa: Cognitive re-structuring, coping with physical arousal, coping with cognitive arousal, dan behavioral skills training.

Fokus terapi dari Novaco (Taylor dan Novaco, 2005) dan Stallard (2005) adalah adanya faktor kognitif yang mempengaruhi tingkah laku seseorang. Dalam proses terapi, subjek akan diberikan pemahaman terlebih dahulu mengenai bagaimana kognitif mempengaruhi tingkah lakunya, serta menelusuri kesalahan berpikir yang dimiliki oleh subjek (Taylor dan Novaco, 2005; Stallard, 2005). Kemudian, kepada subjek juga akan diajarkan berbagai teknik yang dapat digunakan untuk mengurangi atau menghentikan munculnya pikiran -pikiran negatif, serta mencari jalan keluar yang terbaik ketika subjek berhadapan dengan situasi yang tidak menyenangkan dan mencoba menerapkannya ke dalam role-play.

Subjek dalam penelitian ini adalah dua orang anak usia Sekolah Dasar (6-12 tahun) yang berdasarkan assessmen menggunakan wawancara dan observasi memiliki frekuensi perilaku marah yang tinggi, dengan kapasitas IQ rata-rata hingga di atas rata-rata. Hal ini dipilih karena interven si yang akan diberikan menggunakan CBT. Data perilaku marah subjek diperoleh menggunakan behavior checklist yang peneliti buat berdasarkan beberapa perilaku marah yang muncul pada anak menurut Borba (2009). Validitas diperoleh berdasarkan validitas isi. Uji validasi terhadap indicator-indikator aitem behavior checklist dilakukan oleh seorang profesional judgement. Reliabilitas alat ukur penelitian dilakukan oleh tiga orang rater yang dibandingkan dengan menggunakan teknik uji korelasi intra rater (ICC). Hasil uji reliabilitas antar rater dengan ICC, konsistensi nilainya yaitu (ICC=0,978), Sig=.000 yang berarti bahwa hasil penilaian rater 1 , rater 2, dan rater 3 berkorelasi satu sama lain, atau bersifat identik.

Modul Cognitive Behavior Therapy (CBT) pada penelitian ini adalah dengan mengadaptasi prinsip CBT dari Novaco (Taylor dan Novaco, 2005) dan Stallard (2005) yaitu berupa: Cognitive re-structuring, Coping with physical arousal, Coping with cognitive arousal, dan Behavioral skills training yang diuji kualitasnya dengan menggunakan pertimbangan psikolog yang berkompeten dan memiliki pengalaman dalam melakukan intervensi di bidang psikologi, yaitu Ni Made Diyah Rinawardani, S.Psi, Psikolog, dan telah diujicobakan kepada anak yang memiliki kharakteristik seperti subjek pada penelitian ini. Saran perbaikan pada modul yang akan digunakan adalah: 1) Tidak menyatukan dua sesi menjadi satu sesi, walaupun dimungkinkan dapat dilaksanakan dalam satu waktu. Dengan pertimbangan, agar materi dalam setiap sesi betul-betul sudah dim en gerti dan dikuasai oleh subjek, 2) Memperjelas fase kerja yang akan dilaksanakan oleh Pemberi Intervensi 
(PI), 3) Melampirkan lembar kerja yang akan dikerjakan oleh subjek, dan materi yang akan dilaksanakan setiap sesinya.

Desain eksperimen yang digunakan dalam penelitian ini adalah desain eksperimen kasus tunggal (single-case experimental design), dalam bentuk desain eksperimen A-B-A. Desain eksperimen tunggal merupakan sebuah desain penelitian untuk mengevaluasi efek suatu perlakuan (intervensi) dengan kasus tunggal, yang dilakukan untuk mengetahui efek suatu perlaku an dengan jalan membandingkan kondisi atau performansi subjek dari waktu ke waktu dimana subjek diamati perilakunya pada keadaan tanpa perlakuan dan dengan perlakuan secara bergantian (Latipun, 2006), yang digambarkan sebagai berikut:

Tabel 1. Desain Eskperimen Kasus Tunggal A-B-A

\begin{tabular}{lll}
\hline O1 & X & O2 \\
\hline Fase A1 & Fase B & Fase A2 \\
\hline
\end{tabular}

Keterangan:

$\mathrm{O} 1=$ pengukuran kemampuan pengelolaan emosi marah sebelum diberi perlakuan (pretest)

$\mathrm{O} 2=$ pengukuran kemampuan pengelolaan emosi marah sebelum diberi perlakuan (posttest)

$\mathrm{X}=$ Perlakuan yaitu pemberian CBT

Fase $\mathrm{A} 1=$ Fase baseline 1

Fase $\mathrm{B}=$ Fase perlakuan

Fase A2 = Fase baseline 2

Pada desain eksperimen kasus tunggal (single-case experimental design), dalam bentuk desain eksperimen A-B-A yang digunakan dalam penelitian ini, tugas peneliti adalah memastikan perubahan yang terjadi pada perilaku subjek harus merupakan akibat dari adanya manipulasi berupa intervensi menggunakan CBT, dan bukan disebabkan sumber lain (extraneous variable). Extraneous variable yang harus dijaga terutama adalah variabel sosial, yaitu kualitas hubungan antara subjek dan peneliti, dan variabel personal, yaitu kepribadian dari peneliti yang terbawa dan dapat mempengaruhi situasi penelitian.

Pada fase A1 yaitu baseline adalah pengukuran keadaan awal subjek yang dilakukan selama 6 hari sebelum diberikan perlakuan, untuk melihat perilaku marah subjek. Pengukuran fase A1 dilakukan dengan menggunakan behavior checklist yang dilakukan oleh 3 observer, selama 6 hari berturut-turut. Fase A1 adalah fase dimana subjek dalam keadaan natural sebelum mendapat perlakuan.

Fase B adalah fase pemberian intervensi berupa Cognitive Behavior Therapy (CBT) untuk menurunkan perilaku marah subjek dengan mengadaptasi prinsip CBT dari Novaco (Taylor dan Novaco, 2005) dan Stallard (2005) yaitu berupa: Cognitive re-structuring, coping with physical arousal, coping with cognitive arousal, dan behavioral skills training. Pengukuran pada fase B menggunakan behavior checklist sesuai dengan tahapan CBT terhadap subjek selama 6 hari berturut-turut. 
Fase A2 yaitu baseline 2 atau fase penghentian pemberian intervensi dengan CBT pada subjek. Pada fase A2 kembali diukur dengan behavior checklist yang digunakan pada fase A1 dan fase B. Fase A2 berlangsung selama 6 hari berturut-turut. Teknik analisis data yang digunakan dalam penelitian menggunakan metode analisis visual atau visual inspection yaitu analisis data yang menginterpretasikan hasil melalui data grafik secara akurat dan bermakna dengan melihat perubahan yang terjadi dan melihat hubungan perubahan perilaku dengan pemberian intervensi (Cooper, Heron, \& Howard dalam Ayu, 2012).

Analisis selanjutnya menggunakan menggunakan teknik analisis Wilcoxon untuk menguji apakah ada perbedaan frekuensi perilaku marah anak sebelum dan sesudah diberikan intervensi menggunakan Cognitive Behavior Therapy (CBT). Sebagai pendukung data penelitian, peneliti melakukan analisis tambahan berupa analisis kualitatif yang diperoleh dari wawancara yang dilakukan terhadap subjek, orangtua, dan guru yang dilakukan .

\section{HASIL DAN PEMBAHASAN}

Berdasarkan hasil penelitian yang sudah dilaksanakan, dapat disimpulkan bahwa sesuai dengan analisis data kuantitatif, diperoleh hasil ada perbedaan signifikan antara frekuen si perilaku marah sebelum dan sesudah diberikan intervensi dengan menggunakan Cognitive Behavior Therapy (CBT) pada anak usia Sekolah Dasar. Hal ini dapat dilihat pada hasil output analisis menggunakan uji Wilcoxon, diperoleh besaran $\mathrm{Z}=-2,207$ dengan nilai $\mathrm{p}=0,027<0,050$ pada subjek $\mathrm{D}$, dan diperoleh besaran $\mathrm{Z}=-2,201$ dengan nilai $\mathrm{p}=0,028<0,050$ pada subjek A. Analisis data kuantitatif tersebut membuktikan bahwa intervensi CBT efektif dalam menurunkan perilaku marah anak usia Sekolah Dasar.

Efektifitas CBT juga terlihat dari beberapa hal lain, di antaranya adalah hasil visual inspection dari ketiga rater pengamat sebelum, pada saat, dan sesudah pelaksanaan intervensi. Efektifitas CBT juga terlihat dari interpetasi data menggunakan analisis kualitatif pada hasil wawancara sebelum dan sesudah intervensi, dan dari evaluasi pelaksanaan intervensi yang sudah dilakukan terhadap subjek. Terlihat perbedaan kondisi subjek pada saat assessment dan pada saat evaluasi dalam aspek kognitif, emosi, dan perilaku.

Pada aspek kognitif, subjek D dapat merubah pandangannya mengenai konsep sayang. Apabila pada sebelumnya subjek berpandangan bahwa sayang apabila subjek dilayani dan diberikan apa yang subjek mau, namun setelah intervensi subjek dapat memahami bahwa sayang tidak hanya ditunjukkan dari kedua hal tersebut. Dalam aspek emosi, apabila sebelumnya subjek mudah merasa marah dan kesal apabila keadaan tidak sesuai dengan yang subjek inginkan. Setelah intervensi dilakukan, subjek dapat mengurangi ataupun mengendalikan rasa marah yang subjek miliki ketika berhadapan dengan situasi yang tidak menyenangkan. Sedangkan subjek A, pada aspek kognitif, subjek dapat merubah pandangannya terhadap dirinya, bahwa berarti atau tidakn ya seseorang tidak berdasarkan harta yang dipunyai, dan subjek juga menyadari bahwa subjek masih 
mempunyai ibu yang sangat menyayangi subjek. Dalam aspek emosi, apabila sebelumnya subjek mudah merasa marah dan kesal apabila ditanya mengenai diri dan keluarganya, serta mudah merasa iri apabila melihat teman lain yang beraktivitas dengan ayahnya, setelah intervensi dilakukan, subjek dapat mengurangi ataupun mengendalikan rasa marah yang subjek miliki ketika berhadapan dengan situasi yang tidak menyenangkan dan menimbulkan pikiran negatif.

Hasil intervensi memperlihatkan adanya perubahan keyakinan subjek mengenai core belief yang dimilikinya. Informasi dari keluarga juga memperlihatkan adanya penurunan frekuensi kemarahan subjek. Apabila pada saat dilakukan pengukuran sebelum dilaksanakan intervensi subjek dapat marah hampir setiap hari, namun setelah diberikan intervensi baik subjek D maupun subjek A tidak lagi mudah menjadi marah. Selain itu, subjek juga berpendapat bahwa pada awalnya subjek memang merasa sulit untuk mengelola marahnya, namun setelah intervensi subjek sudah memahami apa yang harus subjek lakukan apabila marah apabila menghadapi situasi terten tu yang memancing emosi marah subjek.

Sesuai dengan tujuan dari penelitian, penggunaan intervensi Cognitive Behavior Therapy (CBT) untuk menurunkan perilaku marah pada anak usia Sekolah Dasar adalah efektif. Hal ini dapat dilihat dari perbandingan hasil assessment dan hasil evaluasi yang dilakukan, seperti adanya penurunan perilaku marah subjek sebelum, selama, dan sesudah diberikan intervensi CBT berdasarkan pengamatan dari rater 1, 2, maupun 3 pada subjek D maupun subjek A.

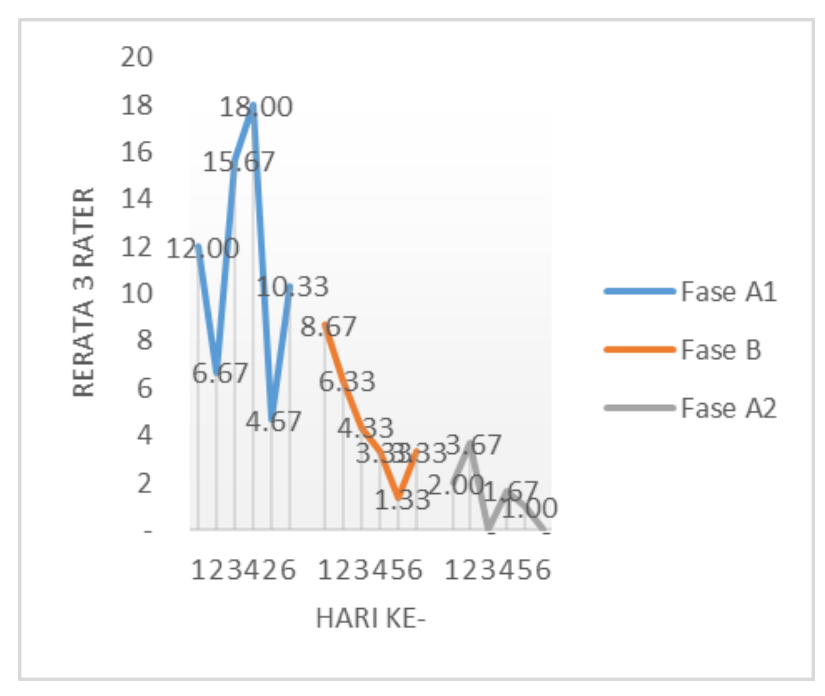

Grafik 1. Analisis data rater 1, 2, 3 pada subjek D 


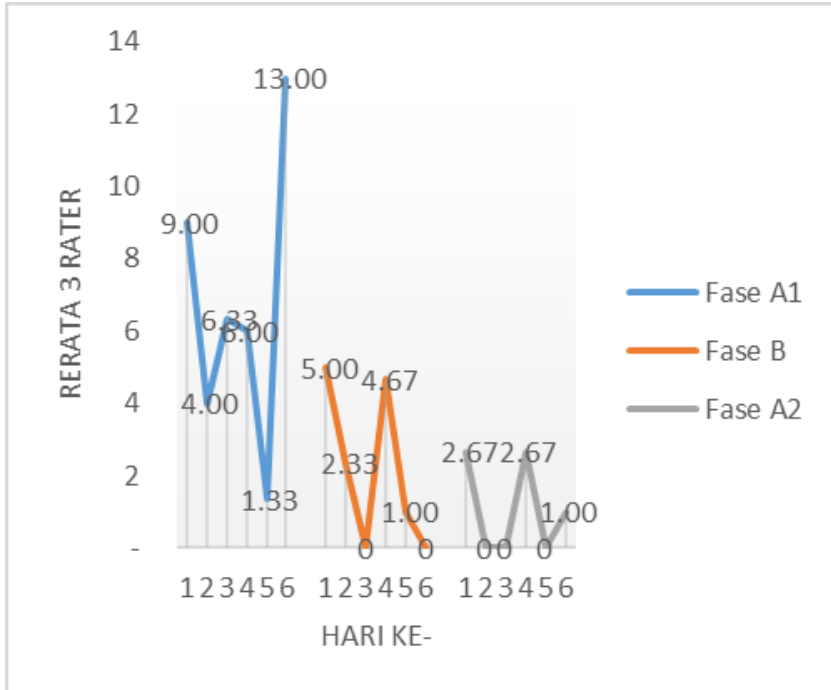

Grafik 2. Analisis data rater 1,2, 3 pada subjek A

Gentry (2007) menyebutkan bahwa seseorang dikatakan memiliki pengelolaan rasa marah yang baik ketika mampu mengendalikan rasa marah yang dimiliki dan memberikan respon terhadap hal tersebut dengan cara yang dapat diterima oleh lingkungan sekitar. Misalnya adalah dengan berkurangnya ekspresi menangis, berteriak atau berbicara dengan suara keras, memaki atau mengeluarkan kata-kata kotor, dan menarik diri di dalam kamar apabila marah. Hal ini sejalan dengan penelitian yang dilakukan oleh Smith, Siegel, O'Connor, dan Thomas (1994) yang menunjukkan adanya efektivitas dari CBT dalam mengurangi masalah yang berhubungan dengan marah, agresi serta tingkah laku disruptif pada anak usia sekolah. Bhave dan Saini (2009) juga berpendapat bahwa dengan mempelajari bagaimana mengelola rasa marah yang baik, dapat mengarahkan individu dalam mengekspresikan marah dalam cara yang positif, dan dapat diterima oleh lingkungan.

Menurut Beck (2011), bagaimana individu bersikap dan merasakan emosi terhadap suatu situasi, dipengaruhi oleh bagaimana individu mempersepsikan lingkungannya. Perubahan kognitif yang terjadi pada subjek, mempengaruhi bagaimana subjek mengelola rasa marah yang subjek miliki. Selain itu, kemampuan subjek untuk mengolah informasi yang diterima, membantunya mengubah core belief yang pada akhirnya mempengaruhi emosi dan tingkah lakunya.

Intervensi dengan Cognitive Behavior Therapy (CBT) untuk menurunkan perilaku marah pada anak usia Sekolah Dasar pada penelitian ini terdiri atas tiga fase yaitu fase pertama (A1), fase kedua (B), dan fase ketiga (A2). Fase pertama (A1) merupakan pengukuran awal perilaku marah pada subjek. Fase ini bertujuan untuk melihat seberapa sering perilaku marah subjek keluar sebelum dikenakan intervensi menggunakan CBT. Pengukuran dilaksanakan 6 hari berturut -t urut, dan digunakan sebagai baseline untuk mengetahui apakah ada penurunan perilaku marah subjek setelah diberikan intervensi menggunakan CBT. 
Fase kedua (B) merupakan pemberian intervensi menggunakan CBT untuk menurunkan perilaku marah subjek. Pengukuran dilaksanakan selama subjek memperoleh intervensi CBT selama 6 hari berturut-turut. Intervensi menggunakan CBT bertujuan untuk men gubah core belief yang dimiliki subjek, sehingga cara pandang subjek dalam menghadapi situasi tertentu berubah yang membantu subjek untuk berperilaku marah yang lebih sesuai dan dapat diterima oleh lingkungannya. Setiap orang memiliki kemampuan mengubah core belief yang berbeda. Ada yang dapat dengan mudah mengubah core belief yang salah, dan ada yang membutuhkan waktu yang lama untuk mengubah core belief-nya. Ketika individu menyadari core belief yang dimilikinya adalah salah, maka akan lebih mudah untuk diubah (Beck, 2011). Begitu juga dengan subjek, baik subjek A maupun subjek D, yang menyadari bahwa core belief yang dimilikinya kurang tepat dan membuatnya sulit dalam mengelola marah sehingga menunjukkan dalam bentuk perilaku dan verbal agresivitas. Kesadaran akan kesalahan core belief membuat hal tersebut tentunya sangat membantu kelancaran proses intervensi yang dilakukan. Faktor lain yang mendukung keberhasilan intervensi ini adalah keinginan subjek untuk dapat berubah. Seperti yang disampaikan oleh Beck (2011), bahwa salah satu yang mendukung keberhasilan dari suatu terapi adalah adanya motivasi dari klien untuk berubah. Sebelum sesi dijalankan, subjek ditanya terlebih dahulu seberapa besar subjek ingin berubah menjadi tidak mudah marah lagi dengan alasan subjek D tidak mau dijauhi teman dan merasa capek, sedangkan subjek A mengatakan ingin lebih mengendalikan ucapannya apabila sedang marah agar tidak menyakiti orang sekitarnya.

Selain hal tersebut di atas, metode penyampaian materi melalui boneka, cerita bergambar, dan worksheet yang bergambar terlihat efektif dalam membantu kelancaran proses komunikasi antara pelaksana intervensi dengan subjek. Seperti yang dikatakan oleh Stallard (2005) bahwa dengan menggunakan media boneka, cerita, cerita bergambar akan membantu klien memahami proses terapi. Selain itu, materi yang disampaikan selalu dihubungkan langsung dengan keadaan subjek yang sesungguhnya. Seperti misalnya situasi yang dapat membuat subjek marah merupakan situasi nyata yang dialami oleh subjek, sehingga subjek tidak mengalami kesulitan dalam membayangkan apa yang dirasakan, pikirkan, dan lakukan dalam situasi tersebut. Hal tersebut juga membuat proses terapi menjadi lebih lancar karena subjek mau membuka diri terhadap pelaksana intervensi (PI).

Materi yang diberikan tidak seluruhnya disampaikan dalam bentuk verbal. Terdapat berbagai gambar yang memudahkan subjek untuk memahami materi. Stallard (2005) menjelaskan bahwa gambar dapat digunakan sebagai visual prompts untuk melakukan psikoedukasi, menggali pikiran pikiran yang mungkin muncul, menarik hubungan antara pikiran dan perasaan. Secara umum Young dan Brown (dalam Stallard, 2002) juga menjelaskan bahwa penerapan CBT terhadap anakanak harus dikemas dalam bentuk yang menyenangkan, menarik dan banyak menggunakan material sebagai alat bantu untuk menyampaikan berbagai konsep, serta disesuaikan dengan usia anak. 
Review atau pengulangan materi sesi setiap kali akan memulai sesi yang baru dianggap cukup efektif. Pelaksana intervensi dapat mengetahui sejauh mana subjek memahami sesi yang telah diberikan, serta memutuskan apakah akan meneruskan ke tahapan terapi yang selanjutnya atau mengulangi sesi yang telah dilakukan. Dari review yang selalu dilakukan, telihat subjek mampu meneruskan tiap sesi tanpa pengulangan sehingga memperlancar proses intervensi. Menurut Beck (2011) bahwa pengulangan atau review sangat membantu dalam proses terapi CBT. Bagi terapis, hal ini berfungsi untuk melihat sejauh mana klien telah memahami proses terapi. Sedangkan bagi klien, hal ini berfungsi untuk membantu mengingat kembali berbagai informasi yang telah diterima.

Intervensi dengan CBT ini juga memiliki beberapa kelemahan, di antaranya adalah pemberian tugas menulis buku harian. Baik subjek D maupun A mengatakan sering lupa untuk mengisinya, dan tidak menyukai menulis. Hal tersebut menjadi salah satu kendala, sehingga informasi yang dapat diperoleh kurang lengkap dan menyeluruh. Kesulitan yang ditemui saat menggunakan intervensi dengan CBT ini adalah saat sesi menggali informasi mengenai pikiranpikiran negatif dan core belief yang dimiliki oleh subjek. Tahapan ini dianggap yang paling sulit karena subjek tidak menyadari apa yang sebenarnya dipikirkan. Sebelumnya pelaksana intervensi tidak memberikan contoh melainkan langsung membahas mengenai pikiran negatif. Setelah dianggap tidak berhasil baru subjek diberikan contoh melalui gambar, soal cerita, dan worksheet sehingga kemudian subjek memahami maksud pikiran negatif yang dimilikinya dan mampu mengungkapkannya kepada pelaksana intervensi. Stallard (2005) mengungkapkan bahwa penggunaan visual prompts berupa gambar dapat digunakan untuk membantu menggali pikiran subjek. Sangat penting mengetahui apa yang subjek senangi serta tokoh idola siapa yang ia kagumi, untuk membantu dalam memberikan berbagai contoh.

Fase terakhir (A2) merupakan fase terakhir dalam pengukuran perilaku marah subjek. Pada fase ini intervensi sudah dihentikan, pengukuran dilaksanakan 6 hari berturut-turut. Pengukuran dilakukan untuk mengetahui efektivitas pemberian intervensi CBT untuk menurunkan perilaku marah subjek. Observasi dan wawancara dilaksanakan untuk mengetahui bagaimana subjek menerapkan cara-cara yang diperolehnya selama memperoleh intervensi CBT untuk menghadapi situasi yang dapat membuat subjek marah. Motivasi yang subjek miliki untuk mengikuti sesi terapi tidak terlalu besar, namun motivasinya untuk dapat berubah menjadi tidak marah lagi yang san gat besar cukup mempengaruhi kelancaran dari intervensi yang dijalankan. Selain itu, dukungan dari keluarga yang juga memberikan dampak positif kepada subjek. Orangtua dan anggota keluarga lainnya selalu memberikan dukungan positif seperti mengatakan "hebat kamu tidak marah lagi sekarang" saat berada di luar terapi dilihat cukup membantu keberhasilan intervensi. Keluarga terkadang dapat diikusertakan ke dalam proses terapi apabila dibutuhkan (Beck, 2011). Subjek D mengatakan dapat dengan mudah menjadi lupa terhadap apa yang telah diajarkan, dan ingin diingatkan. Sedangkan subjek A mengatakan bahwa dia hanya mempunyai ibu dan tidak ingin 
menyakiti hati ibunya lagi. Hal ini membuat peran orangtua atau anggota keluarga lainn ya sangat dibutuhkan.

\section{KESIMPULAN}

Berdasarkan hasil analisis data dan pembahasan, dapat disimpulkan sebagai berikut:

Dari hasil visual inspection, analisis data kuantitatif, dan secara kualitatif membuktikan bahwa intervensi CBT efektif dalam menurunkan perilaku marah anak usia Sekolah Dasar. Sebagai akibat dari intervensi CBT, pada aspek kognitif, dan aspek emosi mengalami perubahan sehingga dapat mengurangi ataupun mengendalikan rasa marah yang subjek miliki ketika berhadapan dengan situasi yang tidak menyenangkan dan menimbulkan pikiran negatif sehingga dapat memunculkan perilaku marah yang dapat diterima oleh lingkungan.

\section{DAFTAR PUSTAKA}

Ayu, T.L. (2012). Program kereta anak tertib untuk menurunkan perilaku distruptif anak taman kanak-kanak. Tesis (Tidak diterbitkan). Yogyakarta: Universitas Gadjah Mada

Beck, J.S. (2011). Cognitive behavior therapy: Basic and beyond (2 ${ }^{\text {nd }}$ ed.). New York: The Guilford Press.

Beck, R., \& Fernandez, E. (1998). Cognitive-behavioral therapy in the treatment of anger: A metaanalysis. Cognitive Therapy and Research, 22(1), 63-74.

Berk, L.E. (2008). Infants, children, and adolescents. ( $6^{\text {th }}$ ed.). USA: Pearson.

Brooks, Jane. (2011). The process of parenting. 8th ed. Singapore: McGraw Hill.

Bhave, S.Y., \& Saini, S. (2009). Anger management. New Delhi, India: Sagepublication.

Borba, M. (2009). The big book of parenting solution. Jakarta: PT Elexmediakomputindo Gramedia.

DiGiuseppe, R., \& Chip, T. (2007). Understanding anger disorders. New York: Oxford.

Faupel, A., Herrick, E., \& Sharp, P. (2011). Anger management: A practical guide. (2nd ed.). Oxon: Routledge

Feindler, E. L \& Engel E. C. (2011). Assesment and intervention for adolescents with anger and agression difficulties in school settings. Psychology in the School, Vol 48(3), p 243-254

Gentry, W.D. (2007). Anger management for dummies. Indiana: Wiley Publishing, Inc.

Geldard, C., \& Geldard, D. (2001). Konseling remaja: Pendekatan proaktif untuk anak muda. Alih Bahasa: Eka A. Yogyakarta: Pustaka belajar.

Geldrad, K., \& Geldrad, D. (2012). Konseling anak-anak. Sebuah pengantar edisi praktis. (3 ${ }^{\text {th }}$ ed). Jakarta: PT. Indeks.

Golden, B. (2003). Healthy anger: How to help children and teens manage their anger. New York: Oxford University Press.

Goleman, D. (1995). Emotional intellegence. Jakarta: Gramedia Pustaka Utama

Goleman, D. (1997). Social intellegence: The new science of human relationship. Jakarta: Gramedia Pustaka Utama

Hidayati, Z., \& Wahyu, R.M. (2015). Time out dalam parenting. Erlangga: Jakarta 
Kail, R.V. (2010). Children and their development (5 $5^{\text {th }}$ ed). USA: Pearson.

Kazdin, A.E., Sigel, T. \& Bass. (1992). Cognitive problem-solving skill training and parent management training in the treatment of antisocial behavioral in children. Journal of Consulting and Clinical Psychology, 57, 733-747.

Kurniawan, Wahyu. (2014). Pengaruh terapi kognitif perilakuan untuk menurunkan gangguan perilaku menentang pada siswa MTS X di Yogyakarta. Tesis (tidak diterbitkan). Yogyakarta. Universitas Mercu Buana.

Latipun. (2006). Psikologi konseling. Malang: UMM Press.

Lemerise, E.A., \& Harper, B.D. (2010). The development of anger from preschool to middle childhood: Expressing, understandingm and regulating anger, dalam Potegal, M., Stemmler, G., \& Spielberger, C. International handbook of anger: Constituent and concomitant biological, psychological, and social processes. USA: Springer.

Mash, E.J., \& Wolfe, D.A. (2012). Abnormal child psychology. Cangage Learning: USA.

Minde, K., Jason, R., \& Hashemi, A. (2010). The effectiveness of CBT in 3-7 year old anxious children: Preliminary data. Journal of the Canadian Academy of Child and Adolescent Psychiatry, 19 (2): 109-115.

Taylor, J.L., \& Novaco, R.W. (2005). Anger treatment for people with developmental disabilities: A theory, evidence and manual based approach. England. John Wiley \& Sons

Santrock, J.W. (2007). Child development, eleventh edition. Jakarta: PT Gelora Aksara Pratama.

Silverman, S., \& DiGiuseppe, R. (2001). Cognitive-behavioral constructs and children's behavioral emotional problems. Journal of Rational-Emotive \& Cognitive Behavior Therapy, 19 (2).

Smith, S.W., Siegel, E.M., O'Connor, A.N., \& Thomas, S. B. (1994). Effects of cognitivebehavioral training on angry behavior and aggression of three-elementary aged students. Behavioral Disorders, 19, 126-135.

Stallard, P. (2002). A cognitive behavior therapy workbook for children and young people. England: John Wiley \& Sons, Ltd.

Cognitive behaviour therapy with children and young people: A selective review of key issues. Journal of Behavioural and Cognitive Psychotherapy, (30), 297-309.

Stallard, P. (2005). A clinician's guide to think good-feel good: Using CBT with children and young people. England: John Wiley \& Sons, Ltd.

Suriadi, R.Y. (2006). Asuhan keperawatan pada anak (Edisi 2). Jakarta: Sagung setia.

Vicker, Bea. (2002). Cognitive behavior therapy for Adolescents with psychological disorders: a group treatment programme. Journal of Clinical Child Psychology and Psychiatry, Vol. 7 (2): $249-262$ 